\title{
Animal performance and sward characteristics of two cultivars of Brachiaria brizantha (BRS Paiaguás and BRS Piatã)
}

\author{
Valéria Pacheco Batista Euclides', Denise Baptaglin Montagner', Rodrigo Amorim Barbosa1, \\ Cacilda Borges do Valle ${ }^{1}$, Nayana Nazareth Nantes ${ }^{2}$
}

\author{
${ }^{1}$ Embrapa Gado de Corte, Campo Grande, MS, Brasil. \\ 2 Universidade Federal de Mato Grosso do Sul, Faculdade de Medicina Veterinária e Zootecnia, Campo Grande, MS, Brasil.
}

\begin{abstract}
The objective of the present study was to evaluate live weight gain per animal and per area and its relationship with the characteristics of pastures of Brachiaria brizantha cv. Paiaguás and Piatã. A randomized blocks experimental design was used, with two treatments and six replicates. The experimental area was 8.0 ha, divided into twelve paddocks of 0.67 ha. The grazing method used was continuous stocking, with variable stocking rate. Three tester steers were used per paddock. Sward heights were measured once a week, and the stocking rate (SR) was adjusted using regulator steers to maintain the sward height at $30 \mathrm{~cm}$. Pasture samples were collected once a month, and herbage accumulation rate (HAR), percentage of leaves (PL), leaf:stem ratio (LSR), and nutritive value (NV) were determined. Animals were weighed every 28 days. No differences between the two cultivars were observed during the wet season for any of the evaluated parameters. However, cv. Paiaguás presented higher HAR and, consequently, higher SR than cv. Piatã during the dry season. As a result of its higher regrowth, cv. Paiaguás pastures presented significantly higher PL, LSR, and NV and, consequently, significantly higher average daily live weight gain. These differences resulted in higher live weight gain per area for Paiaguás grass $(695 \mathrm{~kg} / \mathrm{ha}$ per year) than for Piatã grass (645 kg/ha per year). Thus, Brachiaria brizantha cv. Paiaguás is a good alternative to decrease the temporary forage shortage and for the diversification of pastures in the Cerrado biome region.
\end{abstract}

Key Words: beef cattle, canopy structure, herbage accumulation, nutritive value, stocking rate

\section{Introduction}

One of the factors responsible for low beef cattle production in the tropics is inadequate animal nutrition, resulting mainly from the seasonality of forage production, which is characteristic of tropical regions. Therefore, any effort to increase the availability of quality forage during the dry season will contribute significantly to increasing cattle farming productivity. The use of improved forage plants may help mitigate this problem.

In spite of the great effort of research institutions for the release of new cultivars, the number of cultivars effectively used is still small, and these few cultivars occupy large areas, generating vulnerability in the production systems due to biotic and abiotic factors (Valle et al., 2009; Jank et al., 2011). In addition, the uncertainties regarding climate changes lead to different predictive strategies for breeding programs. However, the seasonality of forage production will still be a limitation present in all scenarios

Received July 30, 2015 and accepted December 3, 2015.

Corresponding author: valeria.pacheco@embrapa.br

http://dx.doi.org/10.1590/S1806-92902016000300001

Copyright (c) 2016 Sociedade Brasileira de Zootecnia. This is an Open Access article distributed under the terms of the Creative Commons Attribution License (http://creativecommons.org/licenses/by/4.0/), which permits unrestricted use, distribution, and reproduction in any medium, provided the original work is properly cited.
(Deconto, 2008), requiring new strategies to meet the animal nutritional demands for the longest period possible.

Nineteen selected accessions of Brachiaria brizantha were evaluated in a Regional Assay Network. The eight accessions that were best in the combined analysis of all tested locations (Valle et al., 2004) were evaluated under grazing, in small plots, four of which were promising and well adapted to the Cerrado biome region (Euclides et al., 2001). Of these accessions, two were selected and tested for animal production: cv. Xaraés, released in 2003, characterized by its high productivity (live weight gain per area), and cv. Piatã, released in 2007, characterized by its high nutritive value, resulting in high animal performance (Euclides et al., 2009). A third ecotype, registered as cv. BRS Paiaguas at the Brazilian Ministry of Agriculture, Livestock and Food Supply (Ministério da Agricultura, Pecuária e Abastecimento - MAPA), presented good agronomical characteristics during the dry season (Euclides et al., 2001). However, studies on the value for cultivation and use of this new cultivar, which provide adequate and reliable information on the new genetic material to its users, are needed before it is placed on the market (MAPA, 2008).

The objective of this study was to evaluate two cultivars of Brachiaria brizantha (Paiaguás and Piatã) to define the best genotype in terms of sward characteristics and animal performance. 


\section{Material and Methods}

The experiment was conducted between June 2009 and May 2012. The climate of the region is a rainy tropical savannah according to the Köppen climate classification, Aw subtype, characterized by seasonal rain distribution, with well-defined occurrence of a dry season during the coldest months of the year. Rainfall, average relative air humidity, and minimum, average, and maximum temperatures (Figure 1) were collected from a meteorological station close to the experimental site. Water balance was calculated (Thornthwaite and Mather, 1955) using the average temperature and accumulated monthly rainfall (Figure 2). The soil water storage capacity used was $75 \mathrm{~mm}$.

The soil at the experimental area is a Dystrophic Red Latosol (Embrapa, 2013). Before pasture establishment, soil samples were collected from the $0-10 \mathrm{~cm}$ layer. Soil chemical characteristics were as follows: $\mathrm{pH}\left(\mathrm{CaCl}_{2}\right) 5.27$, $55.77 \%$ base saturation, $0.84 \%$ aluminum saturation, $5.78 \%$ organic matter, $2.52 \mathrm{mg} \mathrm{dm}^{-3} \mathrm{P}$ (Mehlich 1), and $79.11 \mathrm{mg} \mathrm{dm}^{-3} \mathrm{~K}$ (Mehlich 1).

The soil was corrected with application of $2.25 \mathrm{t} \mathrm{ha}^{-1}$ dolomitic limestone and was fertilized with $400 \mathrm{~kg} \mathrm{ha}^{-1}$ of 0-20-20 and $36 \mathrm{~kg}$ of FTE (35 $\mathrm{g} \mathrm{kg}^{-1}$ of $\mathrm{Zn} ; 35 \mathrm{~g} \mathrm{~kg}^{-1}$ of $\mathrm{Cu} ; 15 \mathrm{~g} \mathrm{~kg}^{-1}$ of $\mathrm{B}$; and $4 \mathrm{~g} \mathrm{~kg}^{-1}$ of Mo). In February 2009, $4.5 \mathrm{~kg} \mathrm{ha}^{-1}$ pure viable seeds of cultivars BRS Piatã and BRS Paiaguás (Brachiaria brizantha) were sown. The seeds were covered by using a locked disk harrow, and soil was compacted using a soil compaction roller. In May, fences were built, and drinking troughs were installed. Topsoil fertilization was performed in October of each year, with application of $40 \mathrm{~kg} \mathrm{ha}^{-1} \mathrm{P}_{2} \mathrm{O}_{5}$ and $\mathrm{K}_{2} \mathrm{O}$. Nitrogen fertilization consisted of $90 \mathrm{~kg} \mathrm{ha}^{-1}$ per year of nitrogen applied as urea, divided into two applications performed in December and February.

The experimental area was 8.0 ha, divided into twelve paddocks of 0.67 ha. The grazing method used was continuous stocking, with a variable stocking rate. A completely randomized blocks experimental design was used, with two treatments and six replicates. The treatments were Brachiaria brizantha BRS Paiaguás and BRS Piatã (control) cultivars.

Sixty Nellore steers, at approximately 7 months old, and with an initial average weight of $180 \pm 8 \mathrm{~kg}$, were used. Three steers were placed in each paddock, in a total of 36 steers. The steers were distributed according to weight so that the average weight in each paddock was the same. The animals remained in the same paddocks for one year as tester animals, when they were replaced with other animals of the same category. The remaining animals were kept at a reserve pasture ( 7.5 ha marandu grass) and were used to adjust the stocking rate to maintain the sward height at $30 \mathrm{~cm}$.

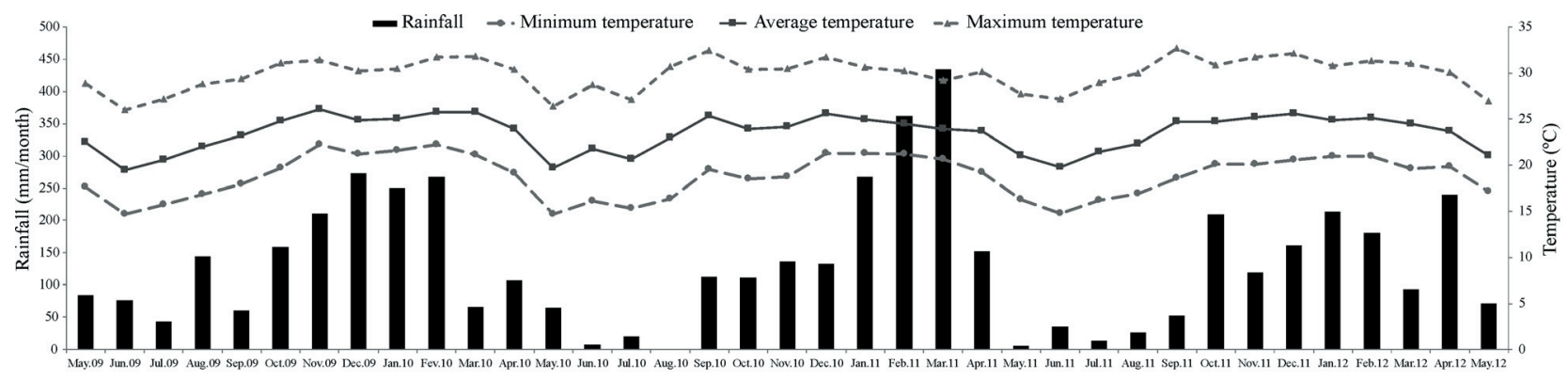

Figure 1 - Rainfall and maximum, average, and minimum temperatures during the experimental period.

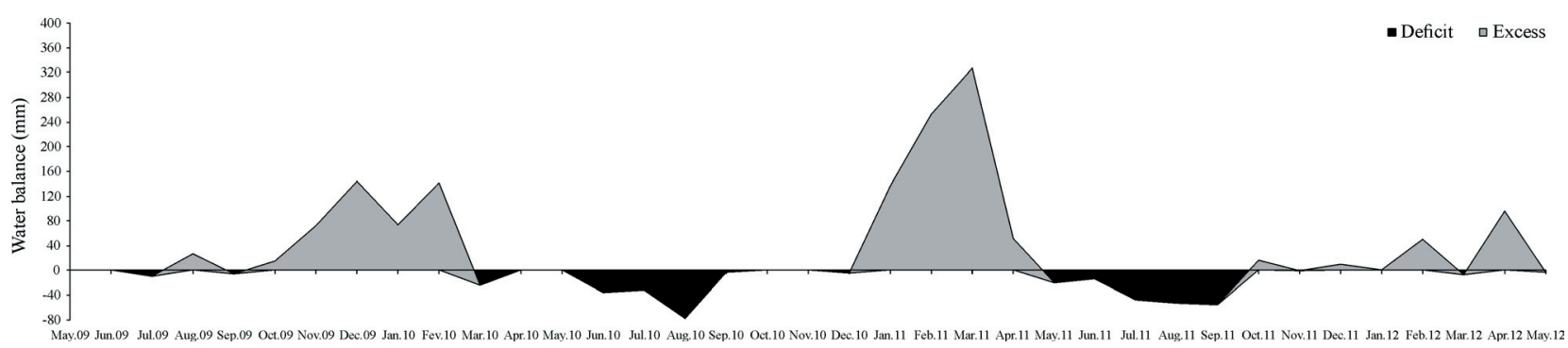

Figure 2 - Water deficit and excess in the soil during the experimental period. 
The animals were treated with a wide spectrum vermifuge at the beginning of the experiment and with pour-on ectocide during the experiment as needed for the control of ticks and horn flies. Animal health management was performed as recommended by the National Beef Cattle Research Center.

The sward height was measured twice a week at 60 random points per experimental unit, using a ruler graduated in centimeters. The height at each point was considered to be the average canopy height surrounding the ruler.

Every 28 days, 15 samples $\left(1 \mathrm{~m}^{2}\right)$ were randomly selected and harvested at ground level in each paddock. The samples were divided into two sub-samples. One sub-sample was weighed, placed in paper bags, dried in a forced-air oven at $55^{\circ} \mathrm{C}$ until constant weight was achieved, and weighed again for estimation of the herbage mass. Composite samples were obtained by combining five subsamples and separated into leaf (leaf blade), stem (stem and sheath), and dead material; the percentage of the total weight for each component was determined. The percentages of each component were used to estimate the leaf:stem and leaf:non-leaf (stem and dead material) ratios.

Herbage accumulation was estimated using three exclusion cages $\left(1 \mathrm{~m}^{2}\right)$ for each paddock. Every 28 days, the cages were placed in points representative of the average canopy height, with similar mass and morphological composition to the areas under grazing. Herbage inside and outside of the cages was harvested at the ground level and sampled as described above; then, herbage mass was determined. Following each harvest, the cages were placed at other points within the paddock according to the same method. Herbage accumulation rate was calculated as the difference between forage mass inside (current harvest) and outside (previous harvest) of the cage, considering only the green part (leaves and stems), divided by the number of days between samplings. Because of a delay in the building of the exclusion cages, herbage accumulation was not estimated for the first experimental year. The herbage allowance (Allen et al., 2011) was calculated by dividing forage mass by the animal live weight in each paddock.

Two samples simulating animal grazing were also collected from each paddock and analyzed to determine crude protein, neutral detergent fiber, and acid detergent lignin concentrations and in vitro organic matter digestibility, by near-infrared spectroscopy (NIRS).

Tester and "grazer" animals were weighed monthly following a 16 -h fast. Daily average weight gain was calculated as the increase in live weight of tester animals divided by the number of days between weighing sessions. The stocking rate was calculated as the product of the average weight of tester and "grazer" animals and the number of days the animals remained in the paddock. Live weight gain per area was calculated as the product of the average daily live weight gain of tester animals and the total number of animals (tester and grazer) per paddock and grazing cycle.

The data were grouped according to the season of the year as follows: dry period, May to September; wet period, October to April. The experimental unit for both vegetation and animal data was the paddock. The data were subjected to an analysis of variance using the MIXED procedure of SAS (Statistical Analysis System, version 9.4). The Akaike information criterion was used to select the covariance matrix (Wolfinger, 1993). The applied model included the random effect of the blocks and the fixed effects of the grass cultivar, experimental year, season of the year, and their interactions. For the stratified herbage samples, the same model was applied, but the effect of the strata was added and considered fixed. Average daily gain (ADG) was analyzed using multivariate repeated measures analysis according to Littell et al. (2000). Means were compared using Tukey's test at $\mathrm{P}<0.05$. When the interactions were significant, means were compared using the probability of difference and the Tukey test at $\mathrm{P}<0.05$. The GLM procedure of SAS (Statistical Analysis System, version 9.4) was used to analyze the total live weight gain per area. Herbage accumulation rate was also analyzed using the method of least squares, using the GLM procedure from SAS (Statistical Analysis System, version 9.4), considering the grass cultivar and experimental year as class variables and their interactions and the month as continuous variables. Based on previous analyses, the highest-order polynomial was selected.

\section{Results}

The sward heights of Paiaguás (paiaguás grass) and Piatã (piatã grass) cultivars remained within the target range during the wet season (Table 1). However, except for the first dry season, because of the low herbage accumulation

Table 1 - Means and standard deviation for real sward heights $(\mathrm{cm})$ of $B$. brizantha cv. Paiaguás and Piatã in different seasons of the year and experimental years

\begin{tabular}{lcclcc}
\hline \multirow{2}{*}{ Experimental year } & \multicolumn{2}{c}{ Dry season } & & \multicolumn{2}{c}{ Wet season } \\
\cline { 2 - 3 } \cline { 6 - 6 } & Paiaguás & Piatã & & Paiaguás & Piatã \\
\hline $2009 / 2010$ & $29.2 \pm 1.3$ & $31.9 \pm 1.3$ & & $30.2 \pm 1.1$ & $31.7 \pm 1.2$ \\
$2010 / 2011$ & $26.0 \pm 2.1$ & $20.7 \pm 2.8$ & & $27.8 \pm 2.2$ & $28.8 \pm 2.1$ \\
$2011 / 2012$ & $27.1 \pm 1.5$ & $26.5 \pm 2.1$ & & $30.1 \pm 1.1$ & $29.1 \pm 1.1$ \\
\hline
\end{tabular}


rate (Table 2) and the small dimensions of the paddocks (0.67 ha), it was not possible to keep the three tester animals in the paddocks and to maintain the target canopy height during the dry season (Table 1). Therefore, it was decided to reduce the stocking rate per paddock during the second and third dry seasons (Table 2).

Herbage mass (HM; $\mathrm{P}=0.5215)$, herbage allowance (HA; $\mathrm{P}=0.2507$ ), percentage of stems (PS; $\mathrm{P}=0.2321$ ), and percentage of dead material (PDM; $\mathrm{P}=0.9633$ ) were not significantly different between the paiaguás and piatã grass pastures. The mean values ( \pm standard error) were $2.870 \pm 70 \mathrm{~kg} \mathrm{ha}^{-1}$ for HM; $3.9 \pm 0.3 \mathrm{~kg}$ herbage dry matter per $\mathrm{kg}$ body weight for HA; $22.6 \pm 0.9 \%$ for PS; and $49.2 \pm 1.6 \%$ for PDM.

However, significant interactions between the cultivar and the season of the year were observed for herbage accumulation rate (HAR; $\mathrm{P}=0.0431)$, percentage of leaves ( $\mathrm{PL} ; \mathrm{P}=0.0321)$, leaf:stem ratio (LSR; $\mathrm{P}=0.0411)$, crude protein $(\mathrm{CP} ; \mathrm{P}=0.0459)$, in vitro organic matter digestibility (IVOMD; $\mathrm{P}=0.0241)$, stocking rate ( $\mathrm{SR} ; \mathrm{P}=0.0334)$, and average daily gain ( $\mathrm{ADG} ; \mathrm{P}=0.0257$ ).

Table 2 - Means and standard errors of the mean (SEM) for herbage accumulation rate, percentage of leaves, leaf:stem ratio, crude protein, in vitro organic matter digestibility, stocking rate, and average daily gain in pastures of $B$. brizantha cv. Paiaguás and Piatã in different seasons of the year

\begin{tabular}{|c|c|c|c|}
\hline \multirow{2}{*}{ Season } & \multicolumn{2}{|c|}{ Cultivar } & \multirow{2}{*}{ SEM } \\
\hline & Paiaguás & Piatã & \\
\hline \multicolumn{4}{|c|}{ Herbage accumulation rate $\left(\mathrm{kg} \mathrm{ha}^{-1} \text { day }\right)^{1}$} \\
\hline Wet & $61.6 \mathrm{aA}$ & $64.1 \mathrm{aA}$ & 3.0 \\
\hline Dry & $17.2 \mathrm{aB}$ & $6.0 \mathrm{bB}$ & 4.1 \\
\hline \multicolumn{4}{|c|}{ Leaves $(\%)$} \\
\hline Wet & $31.5 \mathrm{aA}$ & $32.6 \mathrm{aA}$ & 1.9 \\
\hline Dry & $26.7 \mathrm{aB}$ & $21.7 \mathrm{bB}$ & 1.3 \\
\hline \multicolumn{4}{|c|}{ Leaf:stem ratio } \\
\hline Wet & $1.48 \mathrm{aA}$ & $1.50 \mathrm{aA}$ & 0.12 \\
\hline Dry & $1.30 \mathrm{aB}$ & $1.00 \mathrm{bB}$ & 0.08 \\
\hline \multicolumn{4}{|c|}{ Crude protein $\left(\mathrm{g} \mathrm{kg}^{-1}\right)$} \\
\hline Wet & $105 \mathrm{aA}$ & $97 \mathrm{aA}$ & 2 \\
\hline Dry & $90 \mathrm{aB}$ & $73 b B$ & 3 \\
\hline \multicolumn{4}{|c|}{ In vitro organic matter digestibility $\left(\mathrm{g} \mathrm{kg}^{-1}\right)$} \\
\hline Wet & $598 \mathrm{aA}$ & $589 \mathrm{aA}$ & 6 \\
\hline Dry & $573 \mathrm{aB}$ & $530 \mathrm{bB}$ & 8 \\
\hline \multicolumn{4}{|c|}{ Stocking rate $\left(\mathrm{AU} \mathrm{ha}^{-1}\right)$} \\
\hline Wet & $3.67 \mathrm{aA}$ & $3.78 \mathrm{aA}$ & 0.11 \\
\hline Dry & $1.53 \mathrm{aB}$ & $1.07 \mathrm{bB}$ & 0.14 \\
\hline \multicolumn{4}{|c|}{ Average daily gain $\left(\mathrm{kg}\right.$ animal $\left.{ }^{-1}\right)$} \\
\hline Wet & $0.690 \mathrm{aA}$ & $0.640 \mathrm{aA}$ & 0.04 \\
\hline Dry & $0.350 \mathrm{aB}$ & $0.215 \mathrm{bB}$ & 0.06 \\
\hline
\end{tabular}

${ }^{1}$ Average of two experimental years: 2010/2011 and 2011/2012.

$\mathrm{AU}$ - animal unit.

Values followed by the same uppercase letter within the same column and the same lowercase letter within the same row are not significantly different according to Tukey's test at $\mathrm{P}<0.05$.
No differences in HAR, PL, LSR, CP, IVOMD, SR, and ADG between the cultivars were observed during the wet season. However, HAR, PL, LSR, CP, IVOMD, SR, and ADG were higher for paiaguás grass than for piatã grass pastures during the dry season (Table 2). Regardless of the cultivar, HAR, PL, LSR, CP, IVOMD, SR, and ADG were higher for the wet season than for the dry season (Table 2).

Live weight gain per area was significantly higher $(\mathrm{P}=0.0425)$ for paiaguás grass $\left(695 \pm 15 \mathrm{~kg} \mathrm{ha}^{-1}\right.$ per year $)$ than for piatã grass pastures $\left(645 \pm 15 \mathrm{~kg} \mathrm{ha}^{-1}\right.$ per year).

No significant interactions between the effects of cultivar and season of the year were observed for HM, PS, PDM, and leaf:non-leaf ratio (LNLR) $(\mathrm{P}>0.05)$.

When HAR was analyzed considering the month as a continuous variable, a significant interaction was observed between the effects of the cultivar and the experimental

Table 3 - Mean values for percentage of leaves and average daily gain of animals raised on pastures of $B$. brizantha $\mathrm{cv}$. Paiaguás and Piatã in different seasons of the year and experimental years

\begin{tabular}{lccc}
\hline Season & Year 09/10 & Year 10/11 & Year 11/12 \\
\hline & & Leaves (\%) \\
Wet & $34.5 \mathrm{aA}(1.5)$ & $28.4 \mathrm{aA}(1.6)$ & $33.0 \mathrm{aA}(1.4)$ \\
Dry & $28.8 \mathrm{aB}(1.9)$ & $19.7 \mathrm{bB}(2.6)$ & $21.6 \mathrm{bB}(2.1)$ \\
& & Crude protein $\left(\mathrm{g} \mathrm{kg}^{-1}\right)$ \\
Wet & $102 \mathrm{aA}(3)$ & $106 \mathrm{aA}(3)$ & $96 \mathrm{aA}(2)$ \\
Dry & $92 \mathrm{aA}(4)$ & $72 \mathrm{bB}(4)$ & $80 \mathrm{abB}(4)$ \\
& In vitro organic matter digestibility $\left(\mathrm{g} \mathrm{kg}^{-1}\right)$ \\
Wet & $589 \mathrm{aA}(9)$ & $595 \mathrm{aA}(9)$ & $605 \mathrm{aA}(8)$ \\
Dry & $602 \mathrm{aA}(10)$ & $521 \mathrm{bB}(10)$ & $534 \mathrm{bB}(12)$ \\
& Average daily live weight gain $\left(\mathrm{kg} \mathrm{animal}^{-1}\right)$ \\
Wet & $0.640 \mathrm{aA}(0.04)$ & $0.680 \mathrm{aA}(0.05)$ & $0.670 \mathrm{aA}(0.04)$ \\
Dry & $0.420 \mathrm{aB}(0.07)$ & $0.185 \mathrm{bB}(0.06)$ & $0.250 \mathrm{bB}(0.06)$ \\
\hline
\end{tabular}

Values followed by the same uppercase letter within the same column and the same lowercase letter within the same row are not significantly different according to Tukey's test, at $\mathrm{P}<0.05$.

Standard errors of the mean are indicated between parentheses.

Table 4 - Means and probability (P) levels for herbage mass, herbage allowance, percentage of dead material, leaf:non-leaf ratio, and neutral detergent fiber and acid detergent lignin concentrations in pastures of $B$. brizantha cv. Paiaguás and Piatã in different seasons of the year

\begin{tabular}{lccc}
\hline & \multicolumn{2}{c}{ Season } & \multirow{2}{*}{ P-value } \\
\cline { 2 - 3 } & Wet & Dry & \\
\hline Herbage mass $\left(\mathrm{kg} \mathrm{ha}^{-1}\right)$ & $3075(55)$ & $2660(82)$ & 0.0001 \\
Herbage allowance $(\mathrm{kg} \mathrm{DM} / \mathrm{kg} \mathrm{LW})$ & $2.0(0.2)$ & $5.8(0.3)$ & 0.0001 \\
Dead material $(\%)$ & $44.5(1.9)$ & $54.0(1.3)$ & 0.0001 \\
Leaf:non-leaf ratio & $0.51(0.02)$ & $0.34(0.04)$ & 0.0002 \\
Neutral detergent fiber $\left(\mathrm{g} \mathrm{kg}^{-1}\right)$ & $730(3)$ & $742(4)$ & 0.0461 \\
Acid detergent lignin $\left(\mathrm{g} \mathrm{kg}^{-1}\right)$ & $29(0.5)$ & $33(0.7)$ & 0.0002
\end{tabular}

DM - dry matter; LW - live weight.

Standard errors of the mean are indicated between parentheses. 
year $(\mathrm{P}=0.0324)$. Variation in HAR was best fitted by a third-order polynomial equation, regardless of the cultivar or the experimental year $(\mathrm{P}=0.0001)$, presenting higher values during the summer months, intermediate values during spring and fall, and very low values during winter (Figure 3).
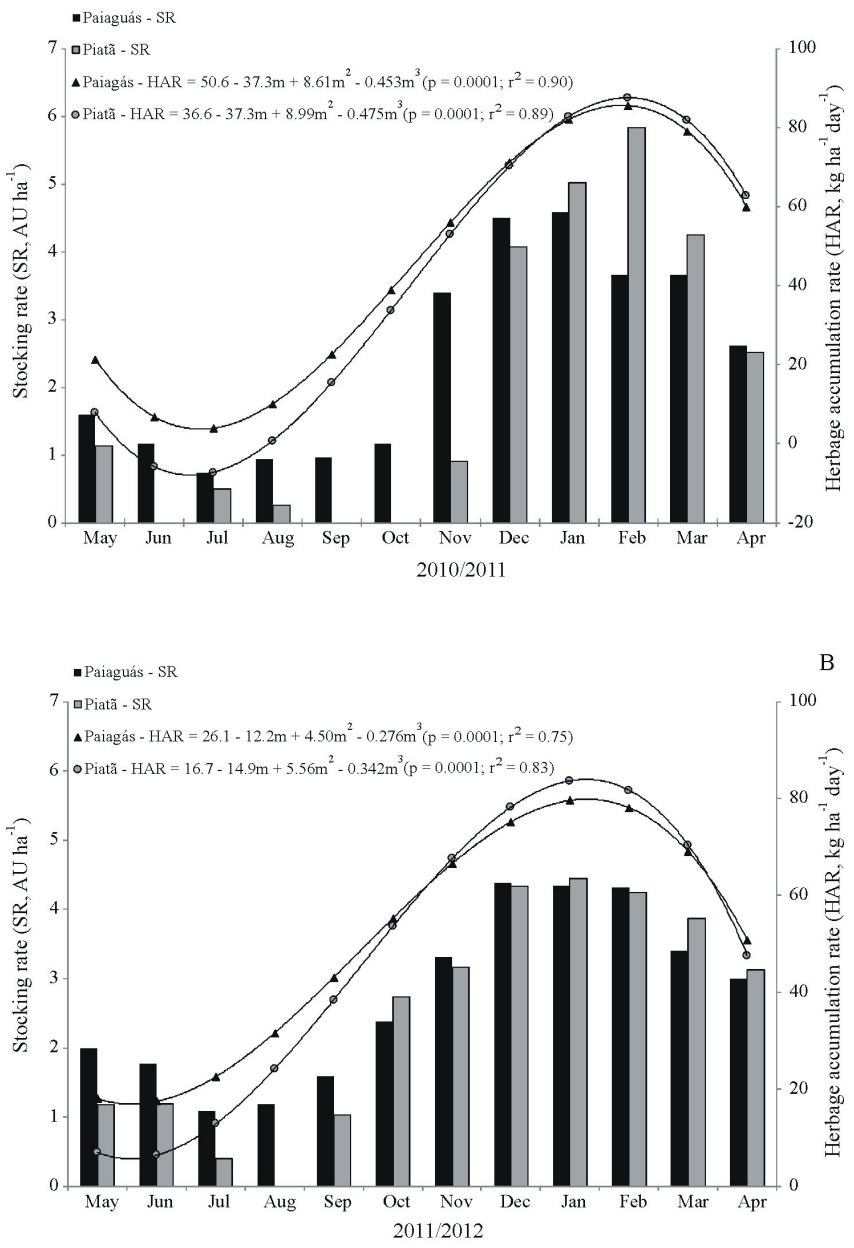

Figure 3 - Monthly distributions of herbage accumulation rate and stocking rate of $B$. brizantha cv. Paiaguás and Piatã pastures from May 2010 to April 2011 (A) and from May 2011 to April 2012 (B).
There were no significant interactions $(\mathrm{P}>0.05)$ between the cultivar and the season of the year for neutral detergent fiber (NDF) and acid detergent lignin (ADL). However, the NDF concentration was significantly lower for paiaguás grass (mean \pm standard error: $72.5 \pm 0.4 \%$ ) than for piatã grass pastures (mean \pm standard error: $74.6 \pm 0.4 \%$ ) $(\mathrm{P}=0.0002)$. The ADL concentration was not significantly different between the two cultivars ( $\mathrm{P}=0.2649)$.

Significant interactions were observed between the season of the year and the experimental year for PL $(P=0.0002), C P(P=0.0210)$, IVOMD $(P=0.0001)$, and ADG $(\mathrm{P}=0.0006)$. Percentage of leaves, CP, IVOMD, and $\mathrm{ADG}$ were higher for the wet than for the dry season and not significantly different between the wet seasons of the three experimental years. However, PL, CP, IVOMD, and ADG were higher for the first dry season $(2009 / 2010)$ than for the second (2010/2011) and third (2011/2012) dry seasons (Table 3).

Herbage mass, HA, PDM, and LNLR were significantly higher and NDF and ADL were significantly lower for the wet than for the dry season (Table 4). The season of the year did not significantly affect PS $(P=0.1651)$.

No significant differences in PS $(\mathrm{P}=0.1852)$, PDM $(\mathrm{P}=0.2542), \operatorname{LSR}(\mathrm{P}=0.8584)$, LNLR $(\mathrm{P}=0.8407)$, NDF $(P=0.0891)$, and ADL $(P=0.6541)$ were observed between experimental years. However, differences between experimental years were observed for the remaining variables quantified (Table 5). Herbage accumulation rate was higher for the third than for the second experimental year, and HM was lower for the second than for the remaining experimental years. Herbage allowance was not significantly different between the first two years and was higher for the third year. Stocking rate and live weight gain per area were higher for the first year, lower for the second year, and intermediate for the third year.

\section{Discussion}

The observed herbage accumulation rate variation (Figures 3A and 3B) was typical for the tropical regions,

Table 5 - Means and probability (P) levels for herbage accumulation rate, herbage mass, herbage allowance, stocking rate, and live weight gain per area, in pastures of $B$. brizantha cv. Paiaguás and Piatã in different experimental years

\begin{tabular}{|c|c|c|c|c|}
\hline & Year 09/10 & Year 10/11 & Year 11/12 & P-value \\
\hline Herbage accumulation rate ( $\mathrm{kg} \mathrm{ha}^{-1}$ day) & - & $33.7(2.5)$ & $41.6(2.6)$ & 0.0287 \\
\hline Herbage mass $\left(\mathrm{kg} \mathrm{ha}^{-1}\right)$ & $3035 \mathrm{a}(76)$ & $2655 \mathrm{~b}(81)$ & $2910 a(87)$ & 0.0027 \\
\hline Herbage allowance ( $\mathrm{kg} \mathrm{DM} / \mathrm{kg} \mathrm{LW})$ & $3.6 \mathrm{~b}(0.4)$ & $3.1 \mathrm{~b}(0.4)$ & $5.2 \mathrm{a}(0.3)$ & 0.0001 \\
\hline Stocking rate $\left(\mathrm{AU} \mathrm{ha} \mathrm{h}^{-1}\right)$ & $3.29 \mathrm{a}(0.17)$ & $1.88 \mathrm{c}(0.15)$ & $2.36 \mathrm{~b}(0.14)$ & 0.0001 \\
\hline Live weight gain per area $\left(\mathrm{kg} \mathrm{ha}^{-1}\right.$ year $)$ & $743 a(18)$ & $588 \mathrm{c}(18)$ & $681 b(18)$ & 0.0015 \\
\hline
\end{tabular}

DM - dry matter; LW - live weight; AU - animal unit.

Means followed by the same letter within the same row are not significantly different according to Tukey's test at $\mathrm{P}<0.05$.

Standard errors of the mean are indicated between parentheses. 
resulting from the rainfall seasonality (Figures 1 and 2) and temperature and photoperiod variations (Figure 1). Similar HAR variations in piatã grass pastures have been previously reported (Euclides et al., 2008; Nantes et al., 2013).

The pronouncedly lower HAR for the dry season, regardless of the grass cultivar (Table 2), resulted mostly from the water stress observed during the dry season (Figures 1 and 2). In spite of the adjustment of the stocking rate (Table 2 and Figure 3), pasture height (Table 1) and herbage mass (Table 4) still decreased, during that season. The decreased leaf (Table 2) and increased dead material (Table 4) percentages were related to the low leaf accumulation and natural senescence of grasses, which was accelerated by the water stress during the dry season (Figure 2) and by grazing, as animals feed mostly on leaves (Brâncio et al., 2003; Trindade et al., 2007). However, the lower percentage of leaves, which are the most nutritive part of the forage, resulted in decreased $\mathrm{CP}$ and IVOMD (Table 3) and increased NDF and ADL (Table 4). Therefore, the unfavorable canopy structure for grazing and the lower nutritive value of the forage explain the lower animal performance observed in the dry than in the wet season (Table 2).

The higher herbage accumulation of the paiaguás grass during the dry season resulted in an approximately $50 \%$ higher stocking rate than that of the piatã grass (Table 2 and Figure 3). This finding is of great importance because the seasonality of forage production is one of the bottlenecks for pasture-raised cattle production. In this context, Valle et al. (2009) emphasized that the seasonality of forage production remains one of the pressing demands for tropical-forage breeding programs.

As a result of its higher regrowth during the dry season, the paiaguás grass presented a higher percentage of leaves and a consequently higher leaf:stem ratio (Table 2). These characteristics are of great importance because diet selection is the main factor affecting the nutritional status of animals (Walker, 1995). Variations in the grazing process, pasture accessibility, and ease of the leaf harvest resulting from changes in canopy structure may therefore significantly influence forage consumption and, consequently, animal performance. Trindade et al. (2007) and Da Silva et al. (2013) showed the importance of pasture structure for the control of forage consumption by animals on marandu grass (B. brizantha) pastures. Therefore, the more favorable canopy structure for grazing (Table 2), together with higher $\mathrm{CP}$ and IVOMD (Table 2), may explain the higher live weight gain observed for pastures of paiaguás grass during the dry season (Table 2).
Another factor that may be related to forage ingestion by animals and consequently to their performance is herbage allowance. Hodgson (1990) suggested that herbage intake would reach its maximum at an herbage allowance of 10 to $12 \mathrm{~kg}$ of dry matter per $100 \mathrm{~kg}$ of body weight. The data indicate that herbage allowance did not limit forage ingestion and consequently live weight gain, during the dry season (Table 4). During the wet season, HA was lower than the optimal value suggested by Hodgson (1990) (Table 4). However, it was also believed to not limit herbage ingestion by animals because herbage accumulation was not considered in the calculation of HA.

The average daily gain observed for cv. Piatã was similar to that reported by Nantes et al. (2013), but lower $(770 \mathrm{~g})$ than that reported by Euclides et al. (2009). The lower performance observed in the present study cannot be attributed to the herbage nutritive value because the average percentages of CP and IVOMD (8.8 and 55.3\%, respectively) for the wet season (Table 3) were higher than those reported by Euclides et al. (2009). However, in the study conducted by Euclides et al. (2008), the canopy structure was more favorable for animal grazing than that of the present study (Table 2), with $41.3 \%$ leaves and a leaf:stem ratio of 1.62 . Therefore, the canopy structure observed in the present study likely led to decreased animal nutrient intake, resulting in a lower ADG. This finding is in accordance with those described by Carvalho et al. (2008), who reported that the presence of stems and dead material at the grazed horizon limited bite depth. Decreased bite depth is commonly associated with increased time per bite, decreased bite rate (Palhano et al., 2007), and increased daily grazing time (Difante et al., 2009).

Thus, differences between the tested grasses were more pronounced for the dry season (Table 2) and were responsible for the higher live weight gain per area observed with paiaguás grass (695 $\mathrm{kg} \mathrm{ha}^{-1}$ per year) than with piatã grass (645 $\mathrm{kg} \mathrm{ha}^{-1}$ per year).

Herbage accumulation rate seasonality was more pronounced during the second experimental year (2010/ 2011) for which HAR was estimated (Figures $3 \mathrm{~A}$ and 3B). This finding may be explained by the worst rainfall distribution during the winter and beginning of spring when compared with the same period of the following year (2011/2012). Together with high temperatures (Figure 1), these conditions resulted in a water deficit that lasted until the beginning of December, whereas in the following year, the soil water level was re-established in the beginning of October (Figure 2). It should be noted that due to the drastic decrease in herbage accumulation in the piatã grass 
pasture (Figure 3A), the target sward height could not be maintained during the second experimental year (Table 1); therefore, it was decided that animals would be removed from the piatã grass paddocks (Figure 3A).

As the criterion used for adjustment of SR was canopy height at $30 \mathrm{~cm}$, the herbage accumulation determined the SR (Figure 3A and 3B). The lower herbage accumulation during the second experimental year (2010/2011) resulted in a lower stocking rate compared with the remaining years (Table 5).

However, the higher ADG observed during the first dry season (Table 5) can be explained by the better rain distribution observed for that period (Figure 1), given that water deficit was only observed in June (Figure 2). This finding indicates higher pasture regrowth, which is in line with the higher PL, CP, and IVOMD (Table 3), along with the higher SR used (average 2.4, 0.6, and 1.1 AU/ha for the first, second and third dry seasons, respectively; Table 5).

The live weight gain per area was approximately $20 \%$ lower for the second year and 10\% lower for the third year compared with the first year (Table 5). These decreases were lower than those reported by Macedo (2006), who estimated $30-40 \%$ higher pasture production and, consequently, animal productivity for the first production year compared with subsequent years, when the production potential was not limited by climate, soil, or inadequate animal handling. It should be highlighted that a part of the decrease between the first and the second year may be attributed to climate conditions, as discussed above.

\section{Conclusions}

Brachiaria brizantha cv. Paiaguás presents distinct advantages over cv. Piatã, especially higher herbage accumulation with better nutritive value during the dry season, resulting in higher performance per animal and per area. These traits suggest that this cultivar might be a new alternative to be used under different production systems, mainly during the dry period, which represents the main constraint as far as feed availability and quality are concerned.

\section{Acknowledgments}

Thanks are expressed to Associação para o Fomento à Pesquisa de Melhoramento de Forrageiras (UNIPASTO), Fundação de Apoio ao Desenvolvimento do Ensino, Ciência e Tecnologia do Estado de Mato Grosso do Sul (FUNDECT-MS), Conselho Nacional de Desenvolvimento Científico e Tecnológico (CNPq), and Comissão de
Aperfeiçoamento de Pessoal do Nível Superior (CAPES), for financial support.

\section{References}

Allen, V. G.; Batello, C.; Berretta, E. J.; Hodgson, J.; Kothmann, M.; Li, X.; McIvor, J.; Milne, J.; Morris, C.; Peeters, A. and Sanderson, M. 2011. An international terminology for grazing lands and grazing animals. Grass and Forage Science 66:2-28.

Brâncio, P. A.; Nascimento Jr., D.; Euclides, V. P. B.; Fonseca, D. M.; Almeida, R. G.; Macedo, M. C. M. and Barbosa, R. A. 2003. Avaliação de três cultivares de Panicum maximum Jacq. sob pastejo: Composição da dieta, consumo de matéria seca e ganho de peso animal. Revista Brasileira de Zootecnia 32:1037-1044.

Carvalho, P. C. F.; Gonda, H. L.; Wade, M. H.; Mezzalira, J. C.; Gonçalves, E. N.; Santos, D. T.; Nadin, L. and Poli, C. H. E. C. 2008. Características estruturais do pasto e consumo de forragem: o que pastar, quanto pastar e como se mover para encontrar o pasto. p.101-130. In: Anais do $4^{\circ}$ Simpósio de Manejo Estratégico da Pastagem. Universidade Federal de Viçosa, Viçosa, MG.

Da Silva, S. C.; Gimenes, F. M. A.; Sarmento, D. O. L.; Sbrissia, A. F.; Oliveira, D. E.; Hernadez-Garay, A. and Pires, A. V. 2013. Grazing behaviour, herbage intake and animal performance of beef cattle heifers on marandu palisade grass subjected to intensities of continuous stocking management. The Journal of Agricultural Science 151:727-739.

Deconto, J. G. 2008. Aquecimento global e a nova geografia da produção agrícola no Brasil. Embrapa/Unicamp, São Paulo.

Difante, G. S.; Euclides, V. P. B.; Nascimento Jr., D.; Da Silva, S. C.; Torres Jr., A. A. R. and Sarmento, D. O. L. 2009. Ingestive behaviour, herbage intake and grazing efficiency of beef cattle steers on Tanzania guinea grass subjected to rotational stocking managements. Revista Brasileira de Zootecnia 38:1001-1008.

EMBRAPA - Empresa Brasileira de Pesquisa Agropecuária. 2013. Sistema Brasileiro de Classificação de Solos. 3.ed. Centro Nacional de Pesquisa de Solos, Rio de Janeiro.

Euclides, V. P. B.; Macedo, M. C. M.; Valle, C. B.; Barbosa, R. A. and Gonçalves, W. V. 2008. Produção de forragem e características da estrutura do dossel de cultivares de Brachiaria brizantha sob pastejo. Pesquisa Agropecuária Brasileira 43:1805-1812.

Euclides, V. P. B.; Macedo, M. C. M.; Valle, C. B.; Difante, G. S.; Barbosa, R. A. and Cacere, E. R. 2009. Valor nutritivo da forragem e produção animal em pastagens de Brachiaria brizantha. Pesquisa Agropecuária Brasileira 44:98-106.

Euclides, V. P. B.; Valle, C. B.; Macedo, M. C. M. and Oliveira, M. P. 2001. Evaluation of Brachiaria brizantha ecotypes under grazing in small plots. p.535-536. In: Proceedings of the 19th International Grassland Congress. FEALQ, São Pedro.

Hodgson, J. 1990. Grazing management: science into practice. John Wiley, New York.

Jank, L.; Valle, C. B. and Resende, R. M. S. 2011. Breeding tropical forages. Crop Breeding and Applied Biotechnology 11:27-34.

Littell, R. C.; Pendergast, J. and Natarajan, R. 2000. Modelling covariance structure in the analysis of repeated measures data. Statistics in Medicine 19:1793-1819.

Macedo, M. C. M. 2006. Aspectos edáficos relacionados com a produção de Brachiaria brizantha cultivar Marandu. p.35-65. In: Morte de pastos de braquiárias. Barbosa, R. A., ed. Embrapa Gado de Corte, Campo Grande.

MAPA - Ministério da Agricultura, Pecuária e Abastecimento. 2008. Requisitos mínimos para determinação do valor de cultivo e uso de Braquiária (Brachiaria brizantha (Hochst. Ex A. Rich.) Stapf, Brachiaria decumbens Stapf, Brachiaria ruziziensis R. Germ. \& 
C. M. Evrard), híbridos e populações resultantes de cruzamentos interespecíficos. Available at: <http://extranet.agricultura.gov. $\mathrm{br} /$ sislegis-consulta/consultarLegislacao.do;jsessionid $=\mathrm{c} 0 \mathrm{a} 802 \mathrm{c} 9$ 30d6480b917add714e568d28eaa8b66cc7ca.e3uQbh0LahaSe34S ahyQahqSbNz0 operacao $=$ visualizar\&id $=18970>$. Accessed on: Jul. 1, 2015.

Nantes, N. N.; Euclides, V. P. B; Montagner, D. B.; Lempp, B.; Barbosa, R. A. and Phillippe, O. G. 2013. Desempenho animal e características de pastos de capim-piata submetidos a diferentes intensidades de pastejo. Pesquisa Agropecuária Brasileira 48:114-121.

Palhano, A. L.; Carvalho, P. C. F.; Dittrich, J. R.; Moraes, A.; Da Silva, S. C. and Monteiro, A. L. G. 2007. Características do processo de ingestão de forragem por novilhas holandesas em pastagens de capim-mombaça. Revista Brasileira de Zootecnia 36:1014-1021.

Thornthwaite, C. W. and Mather, R. J. 1955. The water balance. v.8. Laboratory of Climatology, New Jersey. 104p.

Trindade, J. K.; Da Silva, S. C; Souza Jr., S. J.; Giacomini, A. A.; Zeferino, C. V.; Guarda, V. D. A. and Carvalho, P. C. F. 2007.
Composição morfológica da forragem consumida por bovinos de corte durante o rebaixamento do capim-marandu submetido a estratégias de pastejo rotacionado. Pesquisa Agropecuária Brasileira 42:883-890.

Valle, C. B.; Euclides, V. P. B. Pereira, J. M.; Valério, J. R.; Pagliarini, M. S.; Macedo, M. C. M.; Leite, G. G.; Lourenço, A. J.; Fernandes, C. D.; Dias-Filho, M. B.; Lempp, B.; Pott, A. and Souza, M. A. 2004. O capim-xaraés (Brachiaria brizantha cv. Xaraés) na diversificação das pastagens de braquiárias. Série Documentos no 149. Embrapa Gado de Corte, Campo Grande.

Valle, C. B.; Jank, L. and Resende, R. M. S. 2009. O melhoramento de forrageiras tropicais no Brasil. Revista Ceres 56:460-472.

Walker, J. W. 1995. Viewpoint: grazing management and research now and in the next millenium. Journal Range Management 48:350-357.

Wolfinger, R. 1993. Covariance structure selection in general mixed models. Communications in Statistics - Simulation and Computation 22:1079-1106. 